\title{
Organomineral phosphate fertilization in millet in sandy soil
}

\author{
Maria D. M. Araújo ${ }^{1}$, Henrique A. de Souza ${ }^{2}$, Vinicius M. Benites ${ }^{3}$, Roberto C. F. F. Pompeu ${ }^{4}$, \\ William Natale ${ }^{5}$ \& Luiz F. C. Leite ${ }^{2}$
}

${ }^{1}$ Universidade Estadual Vale do Acaraú/Centro de Ciência Agrárias e Biológicas/Programa de Pós-Graduação em Zootecnia. Sobral, CE, Brasil. E-mail: mariadianamello@gmail.com - ORCID: 0000-0001-7050-1239

${ }^{2}$ Empresa Brasileira de Pesquisa Agropecuária/Embrapa Meio-Norte. Teresina, PI, Brasil. E-mail: henrique.souza@embrapa.br (Corresponding author) - ORCID: 0000-0002-2209-4285; luiz.f.leite@embrapa.br - ORCID: 0000-0001-9648-705X

${ }^{3}$ Empresa Brasileira de Pesquisa Agropecuária/Embrapa Solos. Rio de Janeiro, RJ, Brasil. E-mail: vinicius.benites@embrapa.br - ORCID: 0000-00022602-0750

${ }^{4}$ Empresa Brasileira de Pesquisa Agropecuária/Embrapa Caprinos e Ovinos. Sobral, CE, Brasil. E-mail: roberto.pompeu@embrapa.br - ORCID: 00000002-4099-3575

${ }^{5}$ Universidade Federal do Ceará/Centro de Ciências Agrárias. Fortaleza, CE, Brasil. E-mail: natale@ufc.br - ORCID: 0000-0001-9572-4463

\begin{abstract}
Evaluation of fertilizers is an important premise, given the need for knowing new alternative sources to increase the efficiency in the use of nutrients, especially phosphorus. The objective of this study was to evaluate the growth of millet cultivated in sandy soil under phosphorus doses and sources. The experiment was carried out in a greenhouse, in Sobral, CE, in soil with low phosphorus concentration in the randomized block experimental design, with two sources (monoammonium phosphate - MAP and organomineral fertilizer prepared with MAP and organic compost of waste from small ruminant production - OMF) and four doses of $\mathrm{P}_{2} \mathrm{O}_{5}\left(35,70,140\right.$ and $\left.210 \mathrm{~kg} \mathrm{ha}^{-1}\right)$, plus an additional treatment without phosphate fertilization, with three replicates, conducted in the second half of 2015 . The variables measured were dry mass production, phosphorus accumulation in the plant and agronomic, physiological and recovery efficiencies. Evaluations were carried out in two cuts in millet plants( 65 and 110 days after germination). The data were subjected to analysis of variance, followed by t-test for the sources and regression analysis for the doses, in addition to the Dunnett's test to compare the phosphate fertilization with the control. In the first cut, it was observed that even at low doses of $\mathrm{P}_{2} \mathrm{O}_{5}\left(35 \mathrm{~kg} \mathrm{ha}^{-1}\right.$ of $\left.\mathrm{P}_{2} \mathrm{O}_{5}\right)$, the biomass increases compared to the control. Increment in phosphorus doses increased the accumulation of this nutrient in millet plants. Considering the total accumulated in the two cuts of millet, the organomineral fertilizer promoted higher nutrient content compared to monoammonium phosphate from $127 \mathrm{~kg} \mathrm{ha}^{-1}$ of $\mathrm{P}_{2} \mathrm{O}_{5}$.
\end{abstract}

Key words: Pennisetum glaucum, animal waste, small ruminants

\section{Adubação fosfatada organomineral em milheto em solo arenoso}

RESUMO: A avaliação de fertilizantes é premissa importante, dada à necessidade de conhecer novas fontes alternativas para aumentar a eficiência do uso de nutrientes, principalmente fósforo. Objetivou-se com o presente ensaio avaliar o crescimento da cultura do milheto cultivado em solo arenoso com doses e fontes de fósforo. O experimento foi realizado em casa de vegetação, em Sobral, CE, em solo com baixa concentração de fósforo no delineamento experimental em blocos casualizados, com duas fontes (fosfatomonoamônico - MAP e fertilizante organomineral elaborado com MAP e composto orgânico de resíduos da produção de pequenos ruminantes - FOM) e quatro doses de $\mathrm{P}_{2} \mathrm{O}_{5}\left(35,70,140\right.$ e $\left.210 \mathrm{~kg} \mathrm{ha}^{-1}\right)$, além de tratamento adicional sem adubação fosfatada, com três repetições, conduzido no segundo semestre de 2015. As variáveis mensuradas foram produção de massa seca, acúmulo de fósforo na planta, eficiência agronômica, fisiológica e de recuperação. As avaliações foram realizadas em dois cortes nas plantas de milheto (65 e 110 dias após germinação). Com os dados realizou-se análise de variância seguida do teste de t para as fontes e análise de regressão para as doses, além de teste de Dunnet para comparar a adubação fosfatada com a testemunha. No primeiro corte, constata-se que mesmo em doses baixas de $\mathrm{P}_{2} \mathrm{O}_{5}\left(35 \mathrm{~kg} \mathrm{ha}^{-1}\right.$ de $\left.\mathrm{P}_{2} \mathrm{O}_{5}\right)$, a biomassa aumenta em relação à testemunha. $\mathrm{O}$ incremento das doses de fósforo aumentou o acúmulo deste nutriente em plantas de milheto. Quando analisa-se o acumulado dos dois cortes de milheto, o fertilizante organomineral proporcionou maior conteúdo do nutriente em relação ao fosfato monoamônico a partir de $127 \mathrm{~kg} \mathrm{ha}^{-1} \mathrm{de}_{2} \mathrm{O}_{5}$.

Palavras-chave: Pennisetum glaucum, resíduos animais, pequenos ruminantes 


\section{INTRODUCTION}

Phosphorus (P) deficiency is recognized in Brazilian soils in general, and in the semiarid region, $\mathrm{P}$ is an element that has limiting concentrations (Menezes et al., 2012).

Several studies report that the use of organic composts or even wastes from agricultural or agro-industrial activities can partly meet the $\mathrm{P}$ requirement of agricultural crops (Borges et al., 2019). On the other hand, the combined use of mineral fertilizers with wastes or by-products can enhance or increase P use efficiency (Teixeira et al., 2014; Sá et al., 2017).

Joint application of mineral and organic fertilizers is based on the synergy between these two types, since the organic fertilizer, even at small doses, through the release of organic acids, could reduce $P$ fixation and consequently increase its availability in the soil (Fernandes et al., 2015). However, it is important to consider that there may be a difference of response for organomineral fertilizer according to the organic matrix employed (Corrêa et al., 2016; Frazão et al., 2019).

Using wastes from the production and slaughter of animals as fertilizer is a promising alternative, due to nutrient cycling and the appropriate destination for possible environmental liabilities, and in some cases the disposal of animal waste refers to burying, incineration or even burning, which are not environmentally adequate options (Corrêa et al., 2016; Pierre \& Araújo, 2017). Furthermore, some studies using animal production wastes applied to agricultural crops have shown increments in soil fertility (Nunes et al., 2015; Souza et al., 2016).

Millet assumes importance as a crop used for soil cover in no-tillage systems, in some situations its cultivation as a second crop also aims at grain production and, in semiarid regions, millet has been used to produce forage for use as silage, besides the possibility of using the regrowth. For dry mass yields around $3,300 \mathrm{~kg} \mathrm{ha}^{-1}$, millet extracted around $16 \mathrm{~kg} \mathrm{ha}^{-1}$ of $\mathrm{P}_{2} \mathrm{O}_{5}$ in a study carried out in the Cerrado of Goiás (Pacheco et al., 2011), whereas in Minas Gerais, with dry mass yields around $7,100 \mathrm{~kg} \mathrm{ha}^{-1}, \mathrm{P}$ accumulation was equal to $64 \mathrm{~kg} \mathrm{ha}^{-1}$ of $\mathrm{P}_{2} \mathrm{O}_{5}$ (Perín et al., 2010).

Considering the above, the objective was to evaluate the response of millet to phosphorus doses and sources, with organomineral fertilizer from the composting of wastes from goat/sheep production and slaughter and monoammonium phosphate.

\section{Material ANd Methods}

The experiment was carried out in a greenhouse at Embrapa Caprinos e Ovinos, located in the municipality of Sobral, CE,
Brazil, in the second half of 2015. The physical structure used is equipped with control of relative humidity and temperature, and the mean values along the experiment were $85 \%$ and $28{ }^{\circ} \mathrm{C}$, respectively. In addition, the structure has sprinkler irrigation system, which maintains pot moisture close to $70 \%$ of the total pore volume.

The soil used in the experiment was an Alfisol, collected in Irauçuba, CE, which shows signs of degradation (absence of vegetation cover) and low concentration of $\mathrm{P}$ in the surface layer $(0-0.20 \mathrm{~m})$ (Table 1$)$, besides being a soil representative of the macro-region of Sobral, CE.

The experimental design adopted was in randomized blocks (RCBD) in a factorial $2 \times 4+1$ scheme, with three replicates. The RCBD was chosen because the greenhouse was shaded on one of its sides and due to the presence of expanded clay on one of its sides, which is used to control relative humidity. One of the experimental factors consisted of two sources of phosphate fertilizer, while the other was represented by four $\mathrm{P}$ doses, plus an additional treatment, which was the nonapplication of phosphate fertilizer, whose plots were pots with capacity for $10 \mathrm{dm}^{3}$.

Phosphorus-based fertilizers were monoammonium phosphate $\left(\mathrm{P}_{2} \mathrm{O}_{5}-50 \%\right.$ and $\left.\mathrm{N}-16 \%\right)$ and organomineral fertilizer- OMF $\left(\mathrm{P}_{2} \mathrm{O}_{5}-16 \%, \mathrm{~N}-4 \%\right.$ and $\left.\mathrm{K}_{2} \mathrm{O}-1 \%\right)$, which was produced using as organic matrix a compost $\left(\mathrm{P}_{2} \mathrm{O}_{5}-2.1 \%, \mathrm{~N}-\right.$ $2.1 \%$ and $\mathrm{K}_{2} \mathrm{O}-1.9 \%$ ) generated from wastes of the production and slaughter of goats and sheep (Souza et al., 2019) and, as a mineral matrix, MAP, in the proportion of $67 \%$ of compost and $33 \%$ of MAP. OMF was granulated in a disc granulator, dried at $65^{\circ} \mathrm{C}$ until reaching constant moisture and classified in a sieve with mesh between 1 and $4 \mathrm{~mm}$, all procedures performed by Embrapa Solos (Rio de Janeiro, RJ).

The doses used for $\mathrm{P}$ were 35, 70, 140 and $210 \mathrm{~kg} \mathrm{ha}^{-1}$ of $\mathrm{P}_{2} \mathrm{O}_{5}$, and $70 \mathrm{~kg} \mathrm{ha}^{-1}$ was the standard dose, considering the recommendation of Fernandes (1993). In all experimental units, amounts of $\mathrm{N}$ and $\mathrm{K}$ were increased, when necessary, due to the presence of these nutrients in the sources used (MAP and OMF), applying the equivalent to 36 and $40 \mathrm{~kg} \mathrm{ha}^{-1}$ of $\mathrm{N}$ and $\mathrm{K}_{2} \mathrm{O}$, respectively, at planting and $24 \mathrm{~kg} \mathrm{ha}^{-1}$ of $\mathrm{N}$ as top-dressing. The amounts of nitrogen and potassium were adjusted due to the percentages present in the MAP and OMF, so that there were no differences in the values applied. The sources used were urea for $\mathrm{N}$ and potassium chloride for $\mathrm{K}_{2} \mathrm{O}$. In addition, no lime application was performed because the recommended values of base saturation were close to those recommended for grain crops.

The fertilizers were applied in the furrow, at $5 \mathrm{~cm}$ depth in each pot, but the top-dressing fertilization was performed with

Table 1. Chemical and particle-size characteristics of the Alfisol used in the experiment

\begin{tabular}{|c|c|c|c|c|c|c|c|c|c|c|c|}
\hline \multirow{2}{*}{$\mathrm{pH}$} & \multirow{2}{*}{$\underset{(g \mathrm{dm})}{\mathrm{OM}}$} & $\bar{P}$ & $\bar{K}$ & $\mathrm{Ca}$ & $\mathrm{Mg}$ & $\mathrm{H}+\mathrm{AI}$ & SB & CEC & \multirow{2}{*}{$\begin{array}{c}V \\
(\%)\end{array}$} & $\mathrm{S}^{-\mathrm{SO}_{4}{ }^{2-}}$ & $\overline{\mathrm{Na}}$ \\
\hline & & \multicolumn{2}{|c|}{$\left(\mathrm{mg} \mathrm{dm}^{-3}\right)$} & \multicolumn{5}{|c|}{$\left(\mathrm{mmol}_{\mathrm{d}} \mathrm{dm}^{-3}\right)$} & & \multicolumn{2}{|c|}{$\left(\mathrm{mg} \mathrm{dm}^{-3}\right)$} \\
\hline 5.4 & 5 & 8 & 47 & 16 & 7 & 22 & 26.2 & 48.2 & 54 & 4 & 47 \\
\hline Cu & Fe & $\mathrm{Zn}$ & Mn & B & Clay & \multicolumn{2}{|c|}{ Silt } & Total Sand & \multicolumn{2}{|l|}{ Coarse Sand } & $\begin{array}{l}\text { Fine } \\
\text { Sand }\end{array}$ \\
\hline \multicolumn{5}{|c|}{$\left.(\mathrm{mg} \mathrm{dm})^{-3}\right)$} & \multicolumn{7}{|c|}{$\left(\mathrm{g} \mathrm{kg}^{-1}\right)$} \\
\hline 0.1 & 19 & 0.55 & 8.2 & 0.16 & 72 & & & 880 & 780 & & 100 \\
\hline
\end{tabular}

$\mathrm{pH}$ - Hydrogen potential (in water); OM- Organic matter (Walkley-Black method); P- Phosphorus and K-potassium (Mehlich-1 method); Ca- Calcium, Mg- Magnesium (1 M KCl method); $\mathrm{H}+\mathrm{Al}$-Potential acidity (Ca acetate method); SB- Sum of bases; CEC- Cation exchange capacity; V- Base saturation (calculated variable); S- Sulfur (BaCl ${ }_{2}$ method); NaSodium; Cu-Copper; Fe- Iron; Zn- Zinc; Mn- Manganese (Mehlich-1 method); B-Boron (hot water). Clay, silt and total sand- Pipette method 
dilution in water. Considering the regrowth of millet plants, fertilization was also performed in these plants, but only with $\mathrm{N}$ and $\mathrm{K}_{2} \mathrm{O}$ in the same amounts reported for planting, i.e., 60 and $40 \mathrm{~kg} \mathrm{ha}^{-1}$, respectively.

The experiment was conducted in pots with $9.0 \mathrm{dm}^{3}$ of soil, and 10 millet seeds were sown. Seven days after seedling emergence, thinning was performed, leaving the two most vigorous plants; the experiment was conducted from 65 days after germination to the first cut and, after regrowth, for more 45 days, totaling 110 days.

The variables evaluated were: shoot dry biomass, determined by drying the material in forced air circulation ovens $\left(60^{\circ} \mathrm{C}\right)$ until reaching constant mass, followed by weighing on a precision scale; and $\mathrm{P}$ content in plant tissue, determined after the material was ground (Miyazawa et al., 2009). P content was then multiplied by the total mass of the plants per pot, thus calculating the accumulation of the nutrient per plant. The analyses were performed in the cultivated millet plants and in their regrowth, so that the results of two cuts of the plants are presented.

As a function of the responses of millet plants to the treatments, the following parameters were calculated: agronomic efficiency (production with fertilizer ${ }_{(\mathrm{pot})}$ - production in the control $_{(\text {pot })} /$ applied amount of $\mathrm{P}_{(\mathrm{pot})}$ ); physiological efficiency (production with fertilizer $_{(\mathrm{pot})}-$ production in the control $_{(\mathrm{pot})} /$

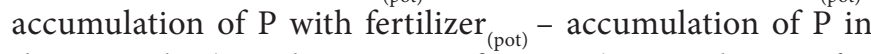
the control $($ pot) $)$; and recovery efficiency (accumulation of $\mathrm{P}$

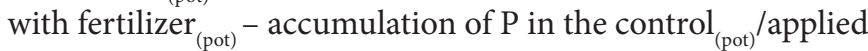
amount of $\left.\mathrm{P}_{(\mathrm{pot})}\right)$ of the applied phosphorus, performed according to Fageria (1998). The two cuts were considered to calculate the efficiencies because the fertilizers were applied all at once.

The data were subjected to analysis of variance and, according to the significance, $\mathrm{F}$ test was performed for the sources of $\mathrm{P}$ and regression analysis for the doses of P. Sources and doses were compared to the control by the Dunnett's test, using R software (version 3.4.2) and the package 'Desc Tools'.

\section{Results AND Discussion}

In relation to the biomass, there was no difference between the types of fertilizers. For the doses, in the first cut, there was a reduction with the amounts applied (Table 2); however, in the second cut, there were no significant results. The reduction in biomass with $\mathrm{P}$ dose in the first cut can be a consequence of the large amounts applied, such as double and three times the recommended dose.

The interaction between sources and doses for dry mass of millet plants in the second cut caused a significant difference, whose results indicate an increment in plant biomass with the amounts that were applied for organomineral fertilizer; for monoammonium phosphate there was no difference between doses (Figure 1).

Considering the result of dry mass in the second cut, when MAP did not cause changes in yield with the doses, unlike OMF, which led to increment in production, this may be an indication of possible residual effect with the use of this source, especially at the higher doses, because the fertilizers were applied at the planting of the crop. Another hypothesis that can be raised but was not measured is the improvement in soil biological activity.

In an experiment with organomineral fertilizer based on poultry litter with four successive corn crops, Sá et al. (2017)

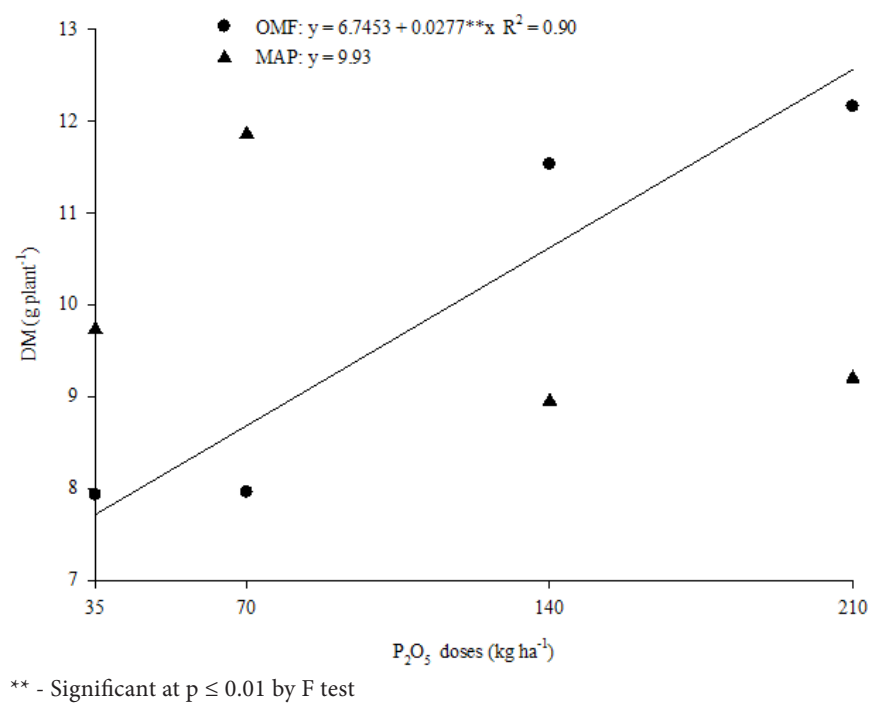

Figure 1. Dry mass of millet plants as a function of $\mathrm{P}_{2} \mathrm{O}_{5}$ doses for different sources, in the second cut

Table 2. Mean values, $F$ test and coefficient of variation for dry mass (DM), phosphorus accumulated in the plant (Pac), and agronomic, physiological and recovery efficiencies of phosphorus, as a function of doses and sources of $\mathrm{P}_{2} \mathrm{O}_{5}$ in millet cultivation

\begin{tabular}{|c|c|c|c|c|c|c|c|c|c|}
\hline \multirow[t]{2}{*}{ Sources - S } & $\mathbf{D M}_{(1 \mathrm{st} \text { cut })}$ & $\mathbf{D M}_{\text {(2nd cut) }}$ & $\mathrm{DM}_{(1 \mathrm{st}+2 \mathrm{nd})}$ & $\mathrm{Pac}_{(1 \mathrm{st} \text { cut })}$ & $\mathrm{Pac}_{\text {(2nd cut })}$ & $\mathrm{PaG}_{(1 \mathrm{st}+2 \mathrm{nd})}$ & $\begin{array}{l}\text { Agronomic } \\
\text { efficiency }\end{array}$ & $\begin{array}{c}\text { Physiological } \\
\text { efficiency }\end{array}$ & \multirow{2}{*}{$\begin{array}{c}\text { Recovery } \\
\text { efficiency } \\
\left(g g^{-1}\right)\end{array}$} \\
\hline & \multicolumn{3}{|c|}{ (g plant $\left.{ }^{-1}\right)$} & \multicolumn{3}{|c|}{ (mg plant $\left.^{-1}\right)$} & \multicolumn{2}{|c|}{$\left(\mathrm{mg} \mathrm{mg^{-1 } )}\right.$} & \\
\hline OMF & 20.3 & 9.9 & 30.2 & 50 & $22 b$ & 72 & 241 & 635 & 0.38 \\
\hline MAP & 21.4 & 9.9 & 31.3 & 48 & $27 \mathrm{a}$ & 75 & 268 & 846 & 0.43 \\
\hline F test & ns & ns & ns & ns & * & ns & ns & ns & ns \\
\hline \multicolumn{10}{|l|}{ 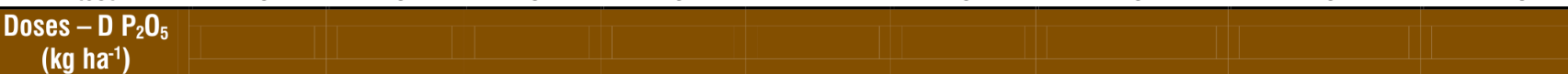 } \\
\hline 35 & 23.2 & 8.8 & 32.0 & 24 & 15 & 39 & 564 & 1539 & 0.39 \\
\hline 70 & 22.6 & 9.9 & 32.5 & 36 & 19 & 55 & 269 & 959 & 0.38 \\
\hline 140 & 18.5 & 10.2 & 28.7 & 58 & 29 & 87 & 106 & 271 & 0.43 \\
\hline 210 & 19.3 & 10.7 & 30.0 & 77 & 35 & 112 & 78 & 193 & 0.41 \\
\hline F test & $\star 1$ & $\mathrm{~ns}$ & $\mathrm{~ns}$ & $\star \star 2$ & $\star * 3$ & $\star \star 4$ & $\star * 5$ & $\star 6$ & $\mathrm{~ns}$ \\
\hline$S \times D$ & $\mathrm{~ns}$ & ** & ns & * & $\mathrm{ns}$ & * & ** & ns & ns \\
\hline CV (\%) & 13.6 & 16.7 & 8.6 & 30.8 & 22.5 & 21.0 & 13.8 & 52.6 & 40.1 \\
\hline
\end{tabular}

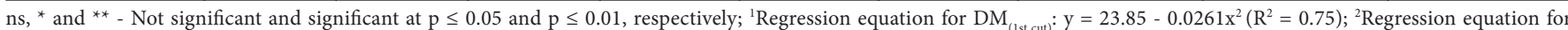
accumulated $\mathrm{P}: \mathrm{y}=14.29+0.3025 \mathrm{x}\left(\mathrm{R}^{2}=0.99\right) ;{ }^{3}$ Regression equation for accumulated $\mathrm{P} \quad \mathrm{y}=11.06+0.116 \mathrm{x}\left(\mathrm{R}^{2}=0.99\right) ;{ }^{4} \mathrm{Regression}$ equation for accumulated $\mathrm{P}$ $y=25.35 .33+0.418381 x\left(R^{2}=0.99\right) ;{ }^{5}$ Regression equation for Agronomic Efficiency: $y=822.3-9.02 x+0.0263 \mathrm{x}^{2}\left(\mathrm{R}^{2}=0.97\right)$; ${ }^{6} \mathrm{Regression}$ equation for Physiological Efficiency: $\mathrm{y}$ $=1606-7.61 \mathrm{x}\left(\mathrm{R}^{2}=0.87\right)$; OMF - Organomineral fertilizer; MAP - Monoammonium phosphate 
found no differences in dry mass yield after the first cultivation, justified by the extraction of nutrients by the crop, but these authors observed results for dry mass accumulation with four successive cuts of corn. However, in the present study the second cut was represented by the regrowth of millet plants and not a new crop, so the plants used part of their reserve. In addition, the possible extractions of nutrients by the crop could justify the absence of difference between the sources and doses (Table 2).

Phosphorus accumulation in millet plants in the first cut did not differ significantly among the studied sources; however, in the second evaluation there was superiority of MAP in comparison to OMF. For the doses (regardless of the source), there was significance for P content in the plant, and the best response model was the increasing linear in the two cuts of millet plants and, consequently, in the sum of $\mathrm{P}$ accumulation (1st cut +2 nd cut) (Table 2$)$.

Regarding the interaction for $\mathrm{P}$ accumulation in the first evaluation, the use of OMF promoted increments with the doses, but for MAP, the maximum accumulation occurred at the $\mathrm{P}_{2} \mathrm{O}_{5}$ dose of $170 \mathrm{~kg} \mathrm{ha}^{-1}$ (Figure 2). Considering $\mathrm{P}$ accumulation in both cuts, there is an increase in the plant with the applied amounts of $\mathrm{P}$ for the two sources, with greater increment using OMF from the $\mathrm{P}_{2} \mathrm{O}_{5}$ dose of $127 \mathrm{~kg} \mathrm{ha}^{-1}$ (Figure 2A).

In the first cut, for the effect of $\mathrm{P}$ doses, regardless of the source, millet plants showed a reduction in dry mass and an increase in $\mathrm{P}$ accumulation. Thus, some inferences may be indicated, such as a possible effect of concentration in the plants, i.e., $\mathrm{P}$ was accumulated, but not metabolized, hence not translating into an increase in dry mass.

For $\mathrm{P}$ accumulation in the first cut (Figure 2A) and the sum of the two accumulations (Figure 2B), when the effect of each source is compared by dose, it can be observed that always at the highest dose used $\left(210 \mathrm{~kg} \mathrm{P}_{2} \mathrm{O}_{5} \mathrm{ha}^{-1}\right)$ there is superiority of OMF in relation to MAP.

In the second cut, when the results for the variables dry mass and $\mathrm{P}$ accumulation for each source were analyzed together, there was a different result; MAP doses did not alter biomass production, but promoted an increase in $\mathrm{P}$ accumulation. However, OMF increased the dry mass production and $\mathrm{P}$ content in the plant.

Thus, the organomineral fertilizer may have reduced $\mathrm{P}$ fixation, enabling better utilization of the nutrient applied, especially from the second cycle of the millet crop. Similar results with organomineral fertilizer, based on residues from sugarcane agroindustry, were observed by Borges et al.(2019), as a possible effect of OMF as slow release fertilizer (Frazão et al., 2019).

Regarding the effect of doses on the agronomic efficiency and physiological efficiency of millet plants, in both cases there was a reduction, and the best response models were quadratic and linear, respectively (Table 2).

Agronomic efficiency was significantly affected by the interaction (doses x sources), and the best response model was exponential for both sources, with reduction in efficiency as the doses employed increased (Figure 3).

The $\mathrm{P}$ recovery efficiency showed no difference between the types of fertilizers and the applied quantities (Table 2).
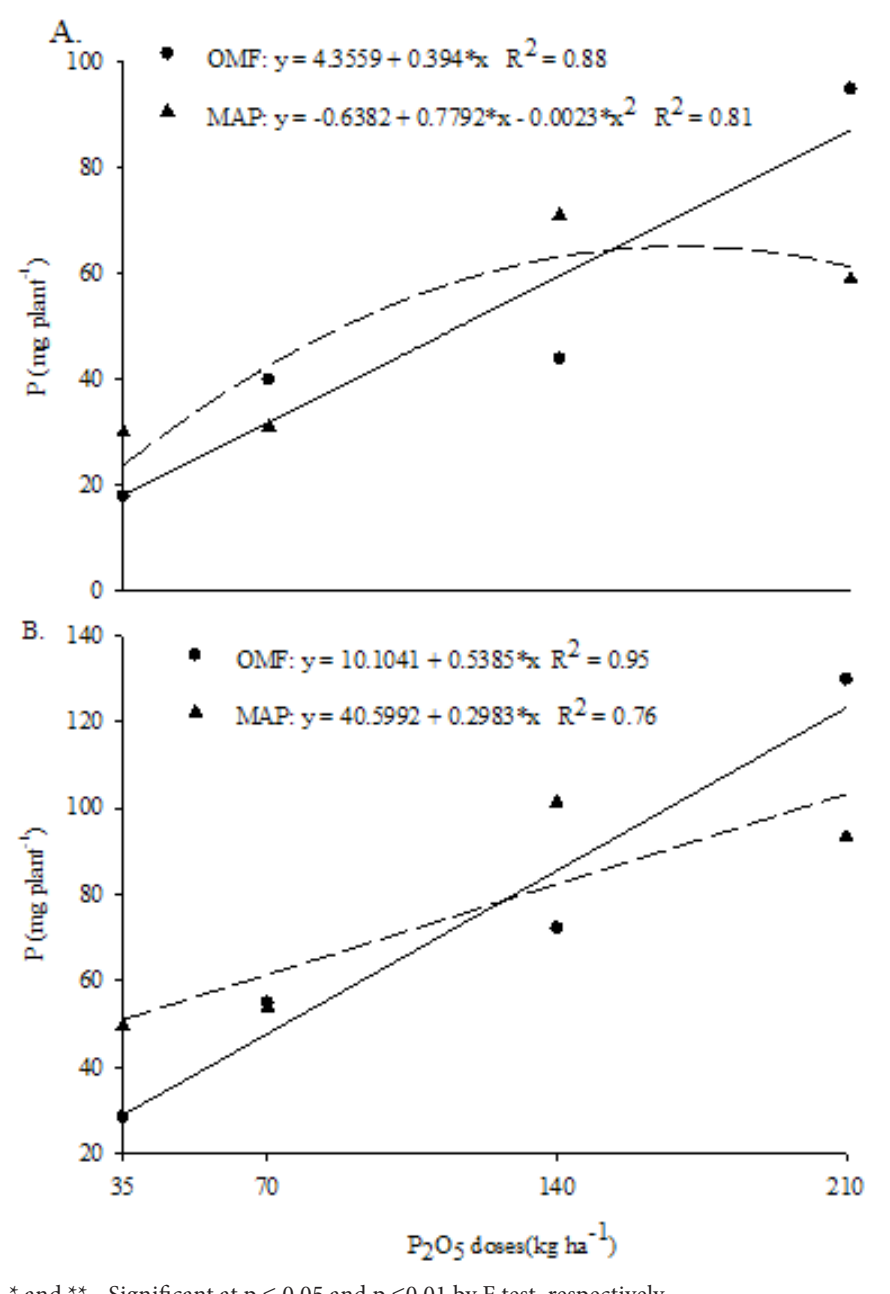

* and ${ }^{* *}$ - Significant at $\mathrm{p} \leq 0.05$ and $\mathrm{p} \leq 0.01$ by $\mathrm{F}$ test, respectively

Figure 2. Phosphorus accumulation in millet plants as a function of $\mathrm{P}_{2} \mathrm{O}_{5}$ doses for different sources, in the first (A) and in the sum of the first and second cuts (B)

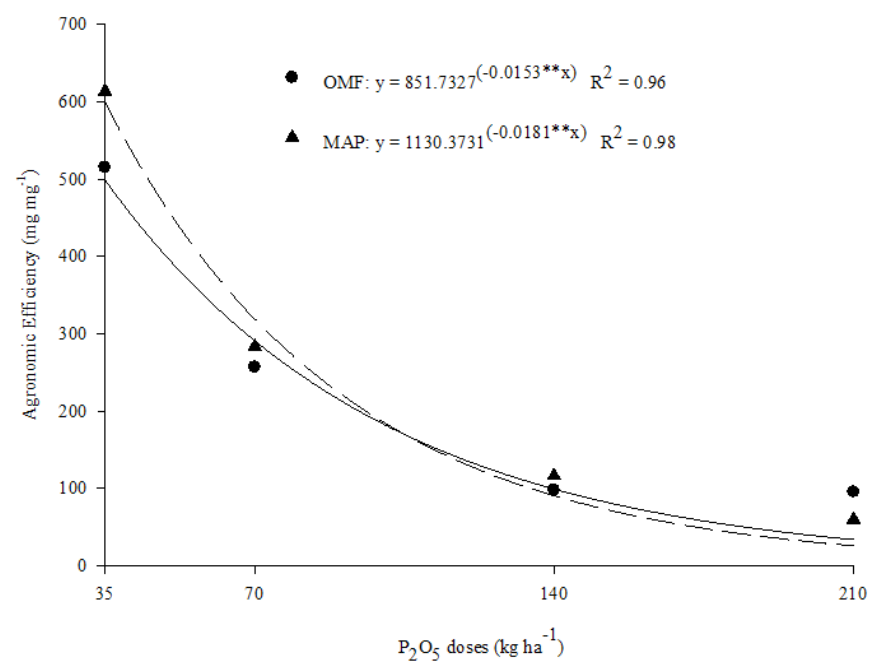

** - Significant at $\mathrm{p} \leq 0.01$ by $\mathrm{F}$ test

Figure 3. Agronomic efficiency in millet plants as a function of $\mathrm{P}_{2} \mathrm{O}_{5}$ doses for different sources

A comparison of MAP with organomineral fertilizer of poultry litter in pots with corn showed no differences for $\mathrm{P}$ recovery rate (Sá et al., 2017). An analogous result also occurred in the comparison of triple superphosphate with organomineral fertilizer from sugarcane production and processing residues (Borges et al., 2019; Frazão et al., 2019). 
Table 3. Mean values of dry mass (DM) and accumulated phosphorus in the plant (Pac) for sources, doses and additional treatment (control - without application of $\mathrm{P}_{2} \mathrm{O}_{5}$ ) in soil cultivated with millet

\begin{tabular}{|c|c|c|c|c|c|c|c|}
\hline \multirow[t]{2}{*}{ Source } & \multirow{2}{*}{$\begin{array}{c}\mathrm{P}_{2} \mathrm{O}_{5} \text { doses } \\
\left(\mathrm{kg} \mathrm{ha}^{-1}\right)\end{array}$} & $\begin{array}{c}\text { DM } \\
\text { (1st cut) }\end{array}$ & $\begin{array}{c}\text { DM } \\
\text { (2nd cut) }\end{array}$ & $\begin{array}{c}\text { DM } \\
\text { (1st+2nd) }\end{array}$ & $\begin{array}{c}\text { Pac } \\
\text { (1st cut) }\end{array}$ & $\begin{array}{c}\text { Pac } \\
\text { (2nd cut) }\end{array}$ & $\begin{array}{c}\text { Pac } \\
(1 s t+2 n d)\end{array}$ \\
\hline & & & $\left(\mathrm{g}\right.$ plant $\left.t^{-1}\right)$ & & \multicolumn{3}{|c|}{ (mg plant $\left.{ }^{-1}\right)$} \\
\hline OMF & 35 & $20.4(+)$ & 8.0 & $28.4(+)$ & 18 & 10 & 28 \\
\hline OMF & 70 & $23.6(+)$ & 8.0 & $31.6(+)$ & 40 & 15 & 55 \\
\hline OMF & 140 & $15.9(+)$ & $11.5(+)$ & $27.4(+)$ & $44(+)$ & 28 & $72(+)$ \\
\hline OMF & 210 & $21.4(+)$ & $12.2(+)$ & $23.6(+)$ & $95(+)$ & $35(+)$ & $130(+)$ \\
\hline MAP & 35 & $26.0(+)$ & 9.7 & $35.7(+)$ & 30 & 19 & 49 \\
\hline MAP & 70 & $21.6(+)$ & $11.9(+)$ & $33.5(+)$ & 31 & 23 & 54 \\
\hline MAP & 140 & $21.0(+)$ & 9.0 & $30.0(+)$ & $71(+)$ & 30 & $101(+)$ \\
\hline MAP & 210 & $17.2(+)$ & 9.2 & $26.4(+)$ & $59(+)$ & $34(+)$ & $93(+)$ \\
\hline \multicolumn{2}{|c|}{ Control } & 6,8 & 8.2 & 15.0 & 11 & 17 & 28 \\
\hline
\end{tabular}

$(+)$ and (-) - Means differ from the control with a higher or lower value, respectively, according to Dunnett's test (5\%); OMF - Organomineral fertilizer; MAP - Monoammonium phosphate

For the dry mass of the first cut, better results were obtained with the use of fertilizers compared to the control (Table 3), regardless of the quantity or source applied. However, in the second cut, the OMF source at the highest doses (140 and 210 $\mathrm{kg} \mathrm{P}_{2} \mathrm{O}_{5} \mathrm{ha}^{-1}$ ) and the MAP source at the dose of $70 \mathrm{~kg} \mathrm{P}_{2} \mathrm{O}_{5} \mathrm{ha}^{-1}$ led to better results of dry mass yield in comparison to the control (Table 3).

The result obtained for biomass, in the first cut, indicates that even low doses of $\mathrm{P}_{2} \mathrm{O}_{5}$, as practiced in the present study ( $35 \mathrm{~kg} \mathrm{ha}^{-1}$ of $\mathrm{P}_{2} \mathrm{O}_{5}$ ), lead to increments compared to the nonapplication (control). For the accumulated dry mass (1st +2 nd cut), there was a difference in all treatments with fertilization compared to the control, that is, the same behavior observed for DM in the first cut.

In the comparison between phosphate fertilization and the control for $\mathrm{P}$ accumulation, in the first cut, better results were obtained at the highest doses ( 140 and $210 \mathrm{~kg} \mathrm{P}_{2} \mathrm{O}_{5} \mathrm{ha}^{-1}$ ) of OMF and MAP, compared to non-application of phosphate fertilizers; in the second cut of millet plants, there were greater accumulations of $\mathrm{P}$ compared to the control for the use of the highest dose $\left(210 \mathrm{~kg} \mathrm{P}_{2} \mathrm{O}_{5} \mathrm{ha}^{-1}\right)$ of the two fertilizers (OMF and MAP) (Table3). For the sum of $\mathrm{P}$ accumulations, the results were analogous to that observed for the first cut, i.e., superiority compared to the control for the highest doses (140 and 210 $\mathrm{kg} \mathrm{P}_{2} \mathrm{O}_{5} \mathrm{ha}^{-1}$ ) of OMF and MAP.

For the second cut, OMF promoted an increase in millet biomass, but MAP did not alter the biomass with the P doses applied. When the average dry mass production obtained with MAP is equaled to the first degree equation of dry mass as a function of OMF doses, there was higher yield with the use of organomineral fertilizer from the $\mathrm{P}_{2} \mathrm{O}_{5}$ dose of $115 \mathrm{~kg} \mathrm{ha}^{-1}$.

In a study conducted with incubation of different $\mathrm{P}$ sources, the application of soluble phosphates and organomineral fertilizer temporarily increased $\mathrm{P}$ availability in the vicinity of the granules $(0-2.5 \mathrm{~cm})$, with maximum availability occurring in approximately 32 days (Morais \& Gatibonie, 2015). In the present study, the cultivation was carried out in sandy soil, contributing to lower P fixation (Donagemma et al., 2016; Sá et al., 2017; Frazão et al., 2019), thus corroborating the possible positive effects of increment inthe accumulation of this nutrient in millet plants.

\section{Conclusions}

1. Phosphorus doses with monoammonium phosphate or organomineral fertilizer derived from organic compost of wastes from the production and slaughter of goats and sheep promoted higher biomass production of millet in the accumulated amount of two cuts compared to the control.

2. In the accumulated amount of the two millet cuts, organomineral fertilizer from organic compost of wastes from the production and slaughter of goats and sheep led to higher nutrient content compare to monoammonium phosphate from high doses of $\mathrm{P}_{2} \mathrm{O}_{5}\left(127 \mathrm{~kg} \mathrm{ha}^{-1}\right)$.

\section{ACKNOWLedgments}

The authors wish to thank the Empresa Brasileira de Pesquisa Agropecuária (Embrapa) for supporting this research (Project no 02.13.05.008.00.08.006). They are indebted to the Brazilian Council for Scientific and Technological Development (CNPq), for granting scholarships for excellence in research $\left(n^{\circ} 311039 / 2017-0\right)$.

\section{Literature Cited}

Borges, B. M. M. N.; Abdala, D. B.; Souza, M. F. de; Viglia, L. M.; Coelho, M. J. A.; Pavinato, P. S.; Franco, H. C. J. Organomineral phosphate fertilizer from sugarcane byproduct and its effects on soil phosphorus availability and sugarcane yield. Geoderma, v.339, p.20-30, 2019. https://doi.org/10.1016/j.geoderma.2018.12.036

Corrêa, J. C.; Grohskopf, M.A.; Nicoloso, R. D.S.; Lourenço, K.S.; Martini, R. Organic, organomineral, and mineral fertilizers with urease and nitrification inhibitors for wheat and corn under notillage. Pesquisa Agropecuária Brasileira, v.51, p.916-924, 2016. https://doi.org/10.1590/S0100-204X2016000800003

Donagemma, G. K.; Freitas, P. L. de; Balieiro, F. de C.; Fontana, A.; Spera, S. T.; Lumbreras, J. F.; Viana, J. H. M.; Araújo Filho, J. C.de; Santos, F. C. dos; Albuquerque, M. R. de; Macedo, M. C. M.; Teixeira, P. C.; Amaral, A. J.; Bortolon, E.; Bortolon, L. Caracterização, potencial agrícola e perspectivas de manejo de solos leves no Brasil. Pesquisa Agropecuária Brasileira, v.51, p.1003-1020, 2016. https://doi. org/10.1590/s0100-204x2016000900001

Fageria, N. K. Otimização da eficiência nutricional na produção das culturas. Revista Brasileira de Engenharia Agrícola e Ambiental, v.2, p 6-16, 1998. https://doi.org/10.1590/1807-1929/agriambi. v02n01p6-16

Fernandes, D.M.; Grohskopf, M.A.; Gomes, E.R.; Ferreira, N.R.; Büll, L.T. Fósforo na solução do solo em resposta à aplicação de fertilizantes fluidos mineral e organomineral. Irriga, v.1, p.1427, 2015. https://doi.org/10.15809/irriga.2015v1n1p14 
Fernandes, V. L. B. Recomendações de adubação de calagem e adubação para o Estado do Ceará. Fortaleza: Imprensa Universitária, 1993. 248p.

Frazão, J. J.; Benites, V. de M.; Ribeiro, J. V. S.; Pierobon, V. M.; Lavres, J. Agronomic effectiveness of a granular poultry litter-derived organomineral phosphate fertilizer in tropical soils: Soil phosphorus fractionation and plant responses. Geoderma, v.337, p.582-593, 2019. https://doi.org/10.1016/j. geoderma.2018.10.003

Menezes, R. S. C.; Sampaio, E. V. S. B.; Giongo, V.; Pérez-Marin, A. M. Biogeochemical cycling in terrestrial ecosystems of the Caatinga Biome. Brazilian Journal of Biology, v.72, p.643-653, 2012. https:// doi.org/10.1590/S1519-69842012000400004

Miyazawa, M.; Pavan, M. A.; Muraoka, T.; Carmo, C. A. F. S. do; Melo, W. J. Análise química de tecido vegetal. In: Silva, F.C. (ed.) Manual de análises químicas de solos, plantas e fertilizantes. Brasília: Embrapa Informação Tecnológica, 2009. p.191-234.

Morais, F. A.; Gatiboni, L. C. Phosphorus availability and microbial immobilization in a Nitisol with the application of mineral and organo-mineral fertilizers. Anais da Academia Brasileira de Ciências, v.87, p.2289-2299, 2015. https://doi.org/10.1590/00013765201520140008

Nunes, W. A. G. de A.; Menezes, J. F. S.; Benites, V. de M.; Lima Junior, S. A. de; Oliveira, A. dos S. Use of organic compost produced from slaughterhouse waste as fertilizer in soybean and corn crops. ScientiaAgricola, v.72, p.343-350, 2015. https://doi. org/10.1590/0103-9016-2014-0094
Pacheco, L. P.; Leandro, W. M.; Machado, P. L. O. de A.; Assis, R. L. de; Cobucci, T.; Madari, B. E.; Petter, F. A. Produção de fitomassa e acúmulo de nutrientes por plantas de cobertura na safrinha. Pesquisa Agropecuária Brasileira, v.46, p.17-25, 2011. https://doi. org/10.1590/S0100-204X2011000100003

Perin, A.; Santos, R. H. S.; Caballero, S. S. U.; Guerra, J. G. M.; Gusmão, L. A. Acúmulo e liberação de P, K, Ca e Mg em crotalária e milheto solteiros e consorciados. Revista Ceres, v.57, p.274-281, 2010. https://doi.org/10.1590/S0034-737X2010000200020

Pierre, F. C.; Araújo, S. M. F. Tratamento de resíduos em frigoríficos de bovino corte. Tekhene e Logos, v.8, p.81-93, 2017.

Sá, J. M.; Jantalia, C. P.; Teixeira, P. C.; Polidoro, J. C.; Benites, V. de M.; Araújo, A. P. Agronomic and P recovery efficiency of organomineral phosphate fertilizer from poultry litter in sandy and clayey soils. PesquisaAgropecuária Brasileira, v.52, p.786-793, 2017. https://doi.org/10.1590/s0100-204x2017000900011

Souza, H. A. de; Melo, M. D.; Primo, A. A.; Vieira, L. V.; Pompeu, R. C. F. F.; Guedes, F. L.; Natale, W. Use of organic compost containing waste from small ruminants in corn production. Revista Brasileira de Ciência do Solo, v.40, p.1-16, 2016. https:// doi.org/10.1590/18069657rbcs20150385

Souza, H. A. de; Oliveira, E. L.; Martins, P. Y. F.; Santiago, L.; Alves Primo, A.; Melo, M. D.; Pereira, G. A. C. Características físicas e microbiológicas de compostagem de resíduos animais. Arquivo Brasileiro de Medicina Veterinária e Zootecnia, v.71, p.291-302, 2019. https://doi.org/10.1590/1678-4162-9735

Teixeira, W. G.; Sousa, R. T. X. de; Korndorfer, G. H. Resposta da cana-de-açúcar a doses de fósforo fornecidas por fertilizante organomineral. Bioscience Journal, v.30, p.1729-1736, 2014. 